【結果】シングルスライスCTでは，検診条件(管電圧 $120 \mathrm{kV}$ ，管電流 $25 \mathrm{~mA}$ ，スライス厚 $10 \mathrm{~mm}$ ) で $1.75 \mathrm{mGy}$ ，精検条件(管電圧 $120 \mathrm{kV}$ ，管 電流 $200 \mathrm{~mA}$ ，スライス厚 $1 \mathrm{~mm}$ ) で $13.5 \mathrm{mGy}$ であった. コーンビーム CTでは，100mAで31.6mGyとなり，シングルスライスCTの検診条件 および精検条件のそれぞれ約18倍, 約2.3倍に相当したが, $32 \mathrm{~mA}$ は $12.3 \mathrm{mGy}$ となりそれぞれ約 7 倍, 約 0.9 倍に低減できた. 画質につ いては光学アイリスの調節により $100 \mathrm{~mA}$ 時と $32 \mathrm{~mA}$ 時とで視覚的お よび定量的に大差はみられなかった。 $10 \mathrm{~mA}$ 時には若干の画質低下 がみられた。

【考察】今回の実験ではコーンビームCTの被曝線量をシングルスライ スCTの精検程度にすることができた。

188 被曝低減システム(Real-EC)における低コントラスト分解能 を考慮した撮影条件について

聖マリアンナ医科大学病院・画像診断センター 園城俊行、森 寿一 前原善昭，吉川達生，小山内司郎

【目的】CT検査の被曝低減手法としてReal-ECが用いられているが，患 者の体格，撮影条件設定方法の違いにより，低コントラスト分解能に 悪影響を及ぼす可能性がある，今回われわれは，低コントラスト分解 能を考慮したReal-ECの使用方法について検討したので報告する.

【方法】東芝社製 Asteion Multi (4DAS)における当院で使用するおもな 撮影条件について，低コントラスト分解能㧍よび画像SDを測定し， 低コントラスト分解能と画像SDとの関係を調べ，最適な撮影条件に ついて検討を行った.

【結果】低コントラスト分解能を考慮し，画像SD值を10以下とするこ とによって検査部位ごとの最低電流を決め，これを基にReal-ECの動 作を設定することで，画質を保ち，低被曝線量による撮影が行える ことが分かった。

【考察】最低許容画像SD值を設定して撮影条件を決定することによっ て，撮影部位ごとに被曝線量の最適化がはかられ，大きな被曝低減 効果が得られた。 また，低コントラスト分解能の劣化を制御し，常 に安定した画質を保つことができた。しかし，現在はスキャン前に 画像SD值が表示されないため，推測で撮影条件を決めている．撮影 時にSD値を設定することで，撮影条件を制御するReal-ECの早期実 用化が望まれる。

189 画質を考慮した被曝低減ソフトウェアの開発 (株)島津製作所·医用機器事業部 今西 達, 味岡智美 医療法人相馬病院 小野山茂樹，大嶋 匡，角市 充，長谷川修平 【目的】体厚に合わせて設定管電流を調整することで，スキャン位置 ごとに適切な線量が与えられるようになり，患者への無駄な被曝を 低減させることができる．このことは同時に画質的に均一なデー夕 が得られることも意味するが，比較的容量の小さいX線管球を搭載 したシステムでは，設定できる最大管電流の制限から設定管電流が 全般にわたって低くなり，均一ではあるが線量が不足気味の画質に なってしまうことがあった，われわれは設定できる管電流が大きく ないシステムにおいても，必要な線量を落とすことなく画質を維持 し, 患者への被曝低減を実現するソフトウェア (Flex-mA画質優先 モード)を開発したので報告する。

【方法】一方向以上の位置決めスキャンょり患者の体厚方向のデータ を算出する．このデータよりスキャン位置ごとの管電流を決めてい くが，このときシステムとして設定できる最大管電流を考慮するこ とで，必要な線量を落とすことのない処理を行う。

【結果】比較的容量が小さく, 設定できる管電流が高くないシステム においても，Flex-mA画質優先モードを使用することにより，必要 な線量を落とすことなく，患者への被曝低減を図ることができた。

【考察】従来の被曝低減を最優先させるモード(被曝低減優先モード) に，今回開発した画質優先モードが加わったことで，患者への被曝
低減方法についても，検査の目的に合わせてそれら使い分けができ るようになる。

\section{0 管電流撮影部位適応機能の開発}

GE横河メディカルシステム(株)・CTマーケティング部 関口淳子 GE横河メディカルシステム(株) - CT技術部 堀内哲也

【目的】肺検診や頭部ルーチンスキャン検查では，検査効率の面か ら，位置決め(スカウト)撮影を行わないことが多い。リアルタイム A u to m A (直前のデータから管電流をリアルタイムに制御する AutomA，第58回総会にて発表)も開発中であるが，より簡便な方法 として位置決め画像(スカウト)を使わない管電流撮影部位適応機能 (Anatomical Fit mA) を開発したので報告する。これは撮影部位に適 応したモデル管電流テーブルを用いることにより，一定の管電流を 用いた場合より被曝線量を低減させる機能である。

【方法】位置決め画像(スカウト)を使用した現行AutomAの臨床デー夕 を用いて, 肺尖部, 肺門部, 肺底部の管電流值をAnatomical Fit mA と比較した。

【結果】現行AutomAと比べて，モデル管電流を用いるため被験者に よっては誤差が生じるものの，一定の管電流で撮影する場合と比較 して被曝線量を低減することが可能であった。このように検査効率 が重視される検査では, Anatomical Fit mAが有用であると考えられ る.

【考察】今後, より精度を高めるためにモデル管電流テーブルを最適 化する一方で, 身長・体重・性別等により最適な管電流テーブルを 選択できる機能等も必要であると思われる.

\section{1 肺ガン検診におけるAnatomical Fit mA 機能の使用経験} NTT東日本伊豆病院 伊賀 功

【目的】短時間で大量の検査を行う集団検診にとって, 検査の効率は 重大な問題である．当院では，これまで肺ガン検診のCT検査におい て, 検查時間の増大を招く位置決め画像(スカウト)の撮影を避け, リアルタイム再構成画像 (SmartRecon)を使用してスキャン終了位置 を判断する手法を用い，管電流值一定での撮影を行ってきた。 今 回，スカウトスキャンを必要としない管電流撮影部位適応機能 (Anatomical Fit mA) を使用する機会を得た，従来の管電流一定での 撮影, また, スカウト使用のAuto $\mathrm{mA}$ と比較して被曝線量および診 断能の比較を行い, 効率的かつ低被曝高画質な肺ガン検診について 検討したので報告する。

【使用機器】CT装置 GE横河メディカル社製 HiSpeed NX/i Pro (ver.5.52)

【方法】ファントムを使用し, 管電流一定, 一般の検査に使用するス カウト使用のAuto mA，およびAnatomical Fit mAの 3 種類について, 使用したmAs值の比較を行い，それぞれの画像について視覚評価を 実施した．また，受検者の肺野の長さに合わせて管電流を変化でき ないAnatomical Fit mAの機構が実際の検査にどの程度影響を与える か人間ドック7,000名を対象に肺野長の統計を取り確認した。

【結果・考察】標準体型の場合Anatomical Fit mAでは, 10mmスライス/ $0.7 \mathrm{sec}$ scan/HSモード $(30 \mathrm{~mm} /$ rotation) にて肺門部の管電流を $14 \mathrm{mAs}$ 程 度まで下げることができ，しかも肺尖部は $56 \mathrm{mAs}$ 程度を確保できる ため, 縦隔病変の存在診断も十分可能であり，低被曝高画質の両立 が可能となった．また, 当初照案だった, 全体の約 $5 \%$ にあたる規 格外の体型に対する対策も管電流を早めに立ち上げることでほほ解 消されることが分かった。 